\title{
Commentary on Dan Arnold, Brains, Buddhas, and Believing: The Problem of Intentionality in Classical Buddhist and Cognitive-Scientific Philosophy of Mind.
}

\author{
Evan Thompson \\ Department of Philosophy \\ University of British Columbia \\ "Taking Buddhist Philosophy of Mind Seriously" \\ Toshide Numata Book Prize Symposium \\ Center for Buddhist Studies \\ University of California at Berkeley \\ November 15, 2013.
}

Dan Arnold's book is a game-changing work of cross-cultural philosophy. Its principal concern is intentionality - the meaningful directedness of the mind toward its objects. Understanding intentionality has been a central problem for modern Western philosophy in both the analytic and phenomenological traditions, as well as for cognitive science. The problem is also central to Indian Buddhist philosophy. Arnold's target is reductionist accounts of intentionality, that is, accounts that would explain intentionality in terms of nonintentional, causal relations. Cognitive science provides one version of such reductionism. According to the computational theory of mind, mental states are computational states of the brain whose content derives from nonintentional information processing and causal interactions with the environment. Indian Buddhism, specifically Dharmakīrti's philosophy, provides a different, nonphysicalist version of reductionism. For Dharmakīrti, mental phenomena, which are immaterial, consist of momentary, particular cognitions, whose patterns of succession are causal (in the sense that there is a constant conjunction of successive events). Mental phenomena, so understood, are entirely impersonal, event-causal occurrences. In addition, for Dharmakīrti, perception is nonconceptual and unmistaken - it apprehends real particulars - whereas thought or conception is mistaken - it apprehends unreal mental constructs. Nevertheless, perception is not direct, because it apprehends its object by way of an aspect ( $\bar{a} k \bar{a} r a)$, which is an imprint left in the mental stream by the causal influence of the object and that functions to represent the form of the object. Furthermore, for Dharmakīti, every perceptual episode is self-cognizing or reflexive, because the aspect or imprint of which the perception is directly aware is that very aspected or imprinted perception itself. In other words, in apprehending an external object via its mental imprint, the perception also reveals itself as the awareness of an immediately given appearance. Thus, Dharmakīrti's reductionism, on Arnold's reading, consists in supposing that intentionality is ultimately reducible to the causation of nonconceptual, momentary, successive, and reflexive perceptual events. Arnold argues that cognitivism and Buddhist reductionism, despite their many differences, share the same basic flaw, which is that intentionality, specifically the conceptually structured, reason-giving practices of persons, cannot be explained in impersonal, event-causal, and nonconceptual terms. In making this argument, he relies on another set of cross-cultural interlocutors. On the one hand, he presents a number of arguments deriving from what I will call the Western 
"conceptualist" lineage of Immanuel Kant, Wilfrid Sellars, and John McDowell; these arguments aim to show that our conceptual capacities and their exercise in cognitionwhat Kant calls "spontaneity" — cannot be explained in merely causal, nonintentional terms, but instead must be seen as sui generis. On the other hand, Arnold deploys three Indian lines of argument that target various problems with Dharmakirti's reductionism. One line of argument is phenomenological and comes from the Śaiva philosopher Bhatta Rāmankaṇtha, who argues that reflexive awareness cannot be momentary, because even momentary episodic awareness requires a background unifying perspective. Another line of argument is linguistic and comes from the Brahmanical tradition of Pūrva Mīmāmsā. Arnold uses this tradition to argue that linguistic intentionality is constitutively social and is a condition of possibility for individual thought, and therefore it cannot be derived (logically or historically) from conventions set up by individuals lacking linguistic capacities (as he takes Dharmakīti's apoha theory of meaning to require). Finally, Arnold uses arguments from the Buddhist Madhyamaka lineage (Nāgārjuna and Candrakirti) to establish that the conventional level of persons and their reason-giving practices is not eliminable from an account of the world, and so cannot be explained in terms of ultimately real impersonal events, as Dharmakīrti's reductionism requires. To summarize, by weaving together these distinct lineages of Indian and Western philosophy, Arnold aims to show that the intentional or meaningful order of persons cannot be eliminated from any account of how the world really is, and therefore that neither Buddhist reductionism nor contemporary cognitivism provides an acceptable account of the mind.

In this short commentary, I cannot do justice to the historical and philosophical richness of Arnold's book. I will accordingly make two main points. My first point will be supportive and will bring out the important critical implications of his book for another cross-cultural philosophical effort he does not discuss-Owen Flanagan's "Buddhism naturalized." Arnold's case on behalf of a Kantian transcendental perspective on the mind combined with a Madhyamaka perspective on the conventional reality of persons and their explanatory practices can be used to show what I take to be problematic in Flanagan's proposal to "naturalize" Buddhism. My second point, however, will be critical and will take issue with Arnold's conceptualism. In my view, conceptualist accounts of intentionality are defective, and so we should not try to build a cross-cultural philosophy of mind on their basis.

\section{Beyond Buddhism Naturalized}

One of the central lines of argument in Arnold's book is a Kantian style transcendental argument to the effect that the intentional and personal level of reason-giving explanation is ineliminable in principle because any attempt to eliminate it in favour of impersonal causal explanations would have to appeal to reasons. Moreover, the first-person perspective of reason-giving is ineliminable, because for me to understand anyone as responsive to reasons requires as a condition of possibility that I understand the other person as doing what I do when I experience myself as acting for a reason. To this Kantian argument, Arnold links a Madhyamaka style argument to the effect that the categories of cause and effect have meaning not by being based on an impersonal objective reality, but by being conventional and pragmatic, reflecting the explanatory 
interests and practices of persons, and so they cannot be used to eliminate the conventional reality of persons in favour of an impersonal event-causal description. One upshot of these arguments, though Arnold does not quite put it this way, is that no objectivist concept of nature - one that by design excludes the intentional-will suffice to account for the mind and its place in nature.

It is precisely this implication that has critical bearing on Flanagan's idea of "Buddhism naturalized." Flanagan does not engage directly with Indian Buddhist philosophy, so he does not consider what Dan's book helps us to see, namely, the elaboration of a Buddhist philosophy of cognitive science that calls into question the standard physicalist notion of "nature" that Flanagan invokes and on which he relies in trying to "naturalize" Buddhism.

Flanagan thinks that because Buddhist epistemology has an empiricist bent, it has the internal resources sufficient to "naturalize" itself. By this he means rejecting the belief in the immateriality of consciousness to make Buddhism consistent with the Darwinian theory of evolution and with "neurophysicalism"- the thesis that every subjective mental event is instantiated by a physical event in the brain, or to put the thesis in a stronger form that Flanagan also favours, is identical to a physical event in the brain.

What Arnold's book enables us to see is that this approach helps itself to a certain conception of nature without subjecting that conception to the kind of philosophical scrutiny that Buddhist philosophy, specifically Madhyamaka, would demand. In this way, Flanagan's project, unlike Arnold's, arguably remains one of cultural appropriation or assimilation - assimilating certain Buddhist ideas to one particular Western viewpoint, instead of allowing the dialogue to subject that viewpoint, too, to philosophical questioning.

Consider that there remains a profound "explanatory gap" between our understanding of the brain and our understanding of consciousness. Moreover, as phenomenologists have long argued, the personal level of meaningful conscious experience has epistemological and methodological primacy in any scientific investigation. Anything we observe, measure, calculate, or model is always disclosed within the domain of conscious experience. Objective and impersonal descriptions map structural and dynamical features of how the world shows itself to us at various spatiotemporal scales. Scientific models are thus distillations of our intersubjective experience as observers, modelers, and interveners. It is therefore strictly nonsensical to reduce the personal level of meaningful conscious experience to one or another of our scientific models, including our models of brain function, for this kind of reduction inverts the necessary epistemological and methodological order of science. The brain is a crucial condition for human consciousness, but our consciousness is not found inside the brain; it resides at the level of the whole embodied, embedded, and enculturated person.

Given this situation, it is crucial to distinguish between naturalism as a general epistemological and methodological stance - the commitment to the possibility of a scientific understanding of the mind - and neurophysicalism, which is a specific metaphysical and reductionist thesis. Naturalism does not entail neurophysicalism. Another naturalist option is that we need to revise our conception of nature to account for intentionality. Moreover, from a Madhyamaka perspective, Flanagan's concept of the "natural" looks like a reification-something erroneously believed to have its own intrinsic and objective reality. The Madhyamaka arguments that negate this concept of 
intrinsic reality imply that whatever counts as "nature" cannot be understood apart from human cognitive practices of investigating nature, and therefore cannot be given absolute explanatory primacy over mind, contrary to the basic premise of "Buddhism naturalized." In this way, Madhyamaka can be seen to parallel Western philosophical critiques of objectivism, especially those found in the phenomenological tradition. One of the great strengths of Arnold's book is that it provides the resources for a cross-cultural philosophical elaboration of this critique, including a specifically Madhyamaka rejoinder to "Buddhism naturalized."

\section{Problems with Conceptualism}

Although I agree with Arnold's insistence on the importance of a transcendental perspective in the philosophy of mind, I do not agree with his conceptualist version of that perspective.

Conceptualism is the thesis that all cognitive capacities are fully determined by conceptual capacities, or that mental content is solely or wholly determined by conceptual capacities. Nonconceptualism is the opposed thesis that cognitive capacities are not fully determined by conceptual capacities, or that mental content can outstrip conceptual capacities. Arnold's expresses conceptualism when he says that something counts as an experience only insofar as it is possible for it to be expressed as the content of a judgement, which is to say that the content of any experience must be specifiable as the content of a proposition. On this view, nonconceptual content — which Dharmakīrti and Western phenomenologists and many philosophers of mind think is constitutive of conscious experience - either does not exist or can play no constitutive role in what we experience.

Conceptualism is an extreme and implausible thesis. It is extreme, because it does not recognize the constitutive presence in experience of nonconceptual content. Such content includes the phenomenal structure of body-centered space and the passive, synthetic, and reflexive experience of time-consciousness, as phenomenologists such as Husserl and Merleau-Ponty describe them (indeed, Husserl's account of timeconsciousness seems very close to Rāmankanțha's). For Kant, of course, space and time are a priori forms of sensibility, but as nonconceptualist readings of Kant make clear, these forms are intuitional, prior to thought, and not conceptual. In addition, nonconceptual content includes the direct perceptual picking out of an object against a background even if there is no corresponding propositional or conceptual description of that object; the perceptual presence of qualitative features, such as particular determinate shades of colour, that are not reidentifiable from moment to moment; the background affect of existential moods such as anxiety, despair, and joy, which are not necessarily expressible as the content of judgements; to say nothing of the possibility of meditative states of absorption or insight that do not have a subject-object or subject-predicate structure (all Indian systems, except maybe the Cārvāka, recognize the possibility of such states). Conceptualism is implausible, because it implies that there exists a sharp break between adult human experience and infant experience, as well as between human and other animal forms of experience. Conceptualism, therefore, makes it extraordinarily difficult to see how there could be the developmental and evolutionary emergence of mind. 
The conceptualist-nonconceptualist debate is lively in contemporary philosophy of mind. In my view, Arnold does not give this debate a proper cross-cultural hearing but instead assumes the Western conceptualist position as an unquestioned vantage point from which to criticize Dharmakirti. Moreover, he seems to suppose that the conceptualist reading of Kant is the only one, contrary to both phenomenological readings and certain contemporary analytic readings that take Kant to uphold the existence and meaningfulness of nonconceptual content in both outer and inner sense. In so doing, Arnold treats the concepts of the intentional or meaningful, the personal, the conceptual, and the conventional (in the Madhyamaka sense) as if they were basically equivalent, whereas they are importantly distinct. Given that the personal level arguably includes nonconceptual forms of intentionality, the personal level is not exhaustively conceptual. In addition, it is not obvious that the Madhyamaka conception of the conventional entails conceptualism; on the contrary, it seems to me that the Mâdhyamika philosopher must deny conceptualism, given the Madhyamaka commitment to the possibility of a direct, nonconceptual cognition of emptiness.

Arnold also ties together two other distinct issues. One issue is whether the intentionality of conscious experience constitutively involves nonconceptual content, and the other issue is whether intentionality is ultimately explainable in impersonal causal terms. Of course, for Dharmakīrti these ideas are tightly connected, but they need not be. One can certainly hold, as I would, that conscious experience can outstrip our conceptual capacities, without holding that intentionality is exhaustively explainable in impersonal causal terms. Indeed, phenomenologists from Husserl to Merleau-Ponty to Dan Zahavi today would deny that intentionality can be explained in impersonal causal terms but would insist on the constitutive presence of nonconceptual content in conscious experience.

Where does this position leave us regarding our cross-cultural dialogue? In my view, the phenomenological viewpoint can provide an important perspective on what I take to be a central commitment of the Buddhist tradition (indeed, arguably of all Indian philosophical traditions), which is the constitutive presence of the nonconceptual in experience. Indeed, without this commitment clearly in view, it would seem impossible to do justice to a whole variety of Buddhist insights into the nature of consciousness, particularly in the philosophies of Vasubandhu, Asanga, Sāntarakșita, and their Tibetan inheritors (such as Mipham), as well as in the context of understanding meditative practices.

As a final point, let me add that although I agree with Arnold that intentionality cannot be explained in impersonal, efficient event-causal terms, I have in my own cognitive-science work argued that complex-system conceptions of causation, in which we find analogues of formal and final causation, may be able to bridge from the domain of physical nature to the domain of what Kant calls "self-organizing being," by which he means the immanent purposiveness of the organism, as well as to the domain of what Kant calls the "spontaneity" of cognition, that is, the capacity to organize and automatically synthesize sensory stimuli in unprecedented ways relative to those stimuli, thereby yielding novel structured cognitions.

Taking these ideas together, we can envision another cross-cultural philosophical project, one that relates Buddhist philosophy, phenomenology, and a nonreductive and embodied, enactive cognitive science. Although our interlocutors would now be 
somewhat different from Arnold's, his book would continue to stand as the model for how such a project should be done. 